\title{
Comparing Socio-Demographic, Health- Related, and Biochemical Factors Associated with Metabolic Syndrome (MetS) between Adolescents from Two Arab Countries
}

\author{
Abdulwahab Naser Al-Isa \\ Department of Community Medicine and Behavioural Sciences, Faculty of Medicine, Kuwait University, Kuwait \\ City, Kuwait \\ Email: alisa@hsc.edu.kw
}

Received 9 January 2014; revised 12 February 2014; accepted 20 February 2014

Copyright (C) 2014 by author and Scientific Research Publishing Inc.

This work is licensed under the Creative Commons Attribution International License (CC BY). http://creativecommons.org/licenses/by/4.0/

(c) (i) Open Access

\begin{abstract}
Background: Studies related to socio-demographic, health-related, and biochemical factors are scarce among Arab adults and even more so among adolescents. Objectives: To compare the above factors between adolescents from two Arab countries. Methods: Two previous studies were done on some of the above factors. The similar factors in the two studies were compared with each other. The two Arab countries that came close to addressing these factors were Kuwait (K) and Egypt (E). Results: Anthropometric measurements were higher among $K$ than $E$ with the exception of Homa-IR, CRP, and homocysteine. All biochemical factors were higher among $K$ than E. The IQ range for gender, age, $\mathrm{WC}$, and area of residence were higher among $\mathrm{E}$ than $\mathrm{K}$. The comparison between $\mathrm{K}$ and $\mathrm{E}$ with respect to the presence of one MetS or more was inconsistent. As the number of MetS increased, K showed higher values of the prevalence MetS than $E$ for either gender or total sample. Conclusions: For individual comparable factors, results were inconsistent. However, with the presence of $\geq 1$ MetS parameter, K showed consistently higher prevalence of MetS.
\end{abstract}

\section{Keywords}

Metabolic Syndrome; Arabs; Factors; Kuwait; Egypt

\section{Introduction}

Lifestyle imposed by modern civilization becomes more and more important factors influencing health state of most developed countries. Unhealthy behaviours are substantially responsible for epidemic prevalence and mor- 
tality of cardiovascular diseases, cancers, diabetes and respiratory disorders [1] [2]. There is increasing body of evidence that following a healthy lifestyle including non-smoking, appropriate diet, satisfactory physical activity level and healthy weight can provide substantial cardiovascular and metabolic benefits [3] [4]. Increased consumption of calorie-dense regular and fast foods, cordials and junk foods which are enriched sources of carbohydrates and fats, together with an increasingly sedentary life-style were shown to be major factors contributing to the obesity epidemic [5].

The metabolic syndrome (MetS) in adults has been defined as a cluster of the most dangerous risk factors for cardiovascular disease and type 2 diabetes, which include abdominal obesity, high cholesterol, high blood pressure, diabetes (if not yet present) and raised fasting plasma glucose [6]. According to International Diabetes Federation (IDF) for adolescents metabolic syndrome definition can be same as that of adults' MetS definition and can be diagnosed with abdominal obesity and the presence of two or more other clinical features (elevated triglycerides or TG, low HDL-cholesterol, high blood pressure, increased plasma glucose) [6]. The prevalence of overweight (BMI $>25 \mathrm{~kg} / \mathrm{m}^{2}$ ) and obesity (BMI $>30 \mathrm{~kg} / \mathrm{m}^{2}$ ) has been on the increase in the Gulf Arab population, primarily among children, adolescents and young adults [7]. In Kuwait, the overall prevalence of overweight and obesity has been found to be $30.9 \%$ and $13.9 \%$, respectively, among adolescents aged $10-14$ years, which probably increased through the years due to the effects of modernisation, increased food consumption and sedentary lifestyles [8] [9].

There are several criteria for the assessment of the MetS, including the criteria produced by the WHO, the European Group for the Study of Insulin Resistance (EGIR), the National Cholesterol Education Program Third Adult Treatment Panel (ATP III) and the International Diabetes Federation (IDF) [10]. Diagnosis of the MetS requires certain risk factors, which are insulin resistance, obesity, hypertension, high TG, reduced HDL-cholesterol level, micro-albumin-uria and elevated plasma glucose. The WHO considered insulin resistance as the major risk factor required for MetS diagnosis. According to the EGIR, the presence of elevated plasma insulin plus two other factors (abdominal obesity, hypertension, elevated TG, reduced HDL-cholesterol or elevated plasma glucose) constitutes a diagnosis of the MetS. The ATP III criterion establishes the diagnosis by the presence of three of five factors of the MetS and there is no single factor required for this diagnosis [11]. The IDF considers the presence of abdominal obesity, in the measure of waist circumference (WC), as the main factor, with two additional risk factors to be sufficient for MetS diagnosis [12]-[14].

\section{Methods}

Two previously published Arab studies, one Kuwaiti and the other Egyptian [13] [14], that dealt with socio-demographic, health-related, and biochemical factors were compared for the similar parameters addressed among adolescents. Capital and non-capital residents in each study were randomly selected. The total sample of 742 Kuwaiti (K) and 4250 Egyptian (E) adolescents were included for each of the two studies. The comparison was made with the fact that Kuwait has much better economic situation than Egypt and Kuwait has far less population than Egypt.

Data analysis: The data were expressed either as frequencies, means $\pm \mathrm{SD}$ /medians (IQ-range) interquartile range with (95\% CI) 95\% confidence interval wherever appropriate. Multivariate logistic regression was also performed to identify variables that were significantly related to the odds of having the MetS. The results are reported as odds ratios with 95\% CIs. Data entry and all analyses were performed with the use of SPSS (Statistical Package for Social Sciences, version 19: SPSS Inc., Chicago, IL, USA). A p-value of $\leq 0.05$ was taken as cut-off point for the value of statistical significance.

\section{Results}

Table 1 shows definitions of risk for MetS parameters on the basis of the National Cholesterol Education program (NCEP). Cut-off values are shown for different parameters including body mass index (BMI), waist circumference and Homa-IR.

Table 2 shows the means \pm SD and 95\% confidence interval which were estimated for the MetS parameters, including age, WC, BMI and biochemical data. Mean age, WC, BMI, SBP (systolic blood pressure), DBP (diastolic blood pressure), and FBG (fasting blood glucose) of Kuwaiti adolescents is almost higher than Egyptians. TG (triglycerides) among Egyptians was higher than Kuwaitis except for the category MetS $\geq 3$ criteria. Egyp- 
Table 1. Definitions of risk for metabolic syndrome (MetS) parameters.

\begin{tabular}{lll}
\hline Parameters & Categories & Risk category definition \\
\hline BMI & & \\
& Not at risk & $<85$ th percentile \\
& Overweight & $\geq 85$ th $-<95$ th percentile \\
& Obese & $\geq 95$ th percentile
\end{tabular}

Waist circumference

$\begin{array}{ll}\text { Not at risk } & <75 \text { th percentile } \\ \text { At risk } & \geq 75 \text { th }-<90 \text { th percentile } \\ \text { Obese } & \geq 90 \text { th percentile }\end{array}$

Fasting blood glucose (FBG)

$\begin{array}{ll}\text { Normal } & <100 \mathrm{mg} / \mathrm{dL} \\ \text { Impaired } & 100-125 \mathrm{mg} / \mathrm{dL} \\ \text { Diabetes } & \geq 126 \mathrm{mg} / \mathrm{dL} \\ \text { Cut-off } & \geq 110 \mathrm{mg} / \mathrm{dL}\end{array}$

SBP/DBP

$\begin{array}{ll}\text { Normal } & <90 \text { th percentile } \\ \text { Pre-hypertension } & \geq 90 \text { th }-<95 \text { th percentile } \\ \text { Hypertension } & \geq 95 \text { th percentile }\end{array}$

TG

$\begin{array}{ll}\text { Normal } & \leq 110 \mathrm{mg} / \mathrm{dL} \\ \text { High } & >110 \mathrm{mg} / \mathrm{dL}\end{array}$

HDL_C

$\begin{array}{ll}\text { Normal } & >40 \mathrm{mg} / \mathrm{dL} \\ \text { Low } & \leq 40 \mathrm{mg} / \mathrm{dL}\end{array}$

HOMA-IR

$\begin{array}{ll}\text { Normal } & <2.5 \\ \text { High } & >2.5\end{array}$

MetS = metabolic syndrome, BMI = body mass index, FBG = fasting blood glucose, HDL = high density lipoprotein, TG = triglycerides, SBP = systolic blood pressure, DBP = diastolic blood pressure.

tian adolescents had almost higher HDL-C, CRP (C-reaactive protein) and homocysteine. This is not consistent in case of Insulin and Homa-IR, where Kuwaitis had mostly higher values than Egyptians.

Table 3 shows medians with IQ (Interquartile) ranges for CRP and homocysteine which were higher for Egyptian adolescents for certain factors like age, gender, waist circumference and area of residence than Kuwaitis.

Table 4 shows that in one parameter Kuwaitis were consistently higher and in two or more parameters Egyptians were consistently higher than Kuwaitis. In all parameters (total) Kuwaitis were higher except for TG.

Figure 1 compares the prevalence of MetS between adolescents of Kuwait and Egypt. As the number of MetS parameters increased, Kuwaiti adolescents showed higher prevalence values. While comparing among different MetS criteria all groups were statistically significant (p-values $<0.01$ )

Figure 2 compares the prevalence of MetS between male adolescents of Kuwait and Egypt. Under healthy conditions, they were the same for one parameter, and higher for Kuwaiti adolescents when two and three para- 
Table 2. Comparing socio-demographic, health-related, and biochemical factors associated with metabolic syndrome (MetS) between adolescents from two Arab countries, Kuwait and Egypt.

\begin{tabular}{|c|c|c|c|c|c|c|c|c|c|c|}
\hline & \multicolumn{2}{|c|}{$\begin{array}{c}\text { Normal } \\
\text { Mean } \pm \text { SD } \\
95 \% \text { CI }\end{array}$} & \multicolumn{2}{|c|}{$\begin{array}{c}\frac{\text { One criterion }}{\text { Mean } \pm \text { SD }} \\
95 \% \text { CI }\end{array}$} & \multicolumn{2}{|c|}{$\begin{array}{c}\frac{\text { Two criteria }}{\text { Mean } \pm \text { SD }} \\
95 \% \text { CI }\end{array}$} & \multicolumn{2}{|c|}{$\begin{array}{c}\text { MS }(\geq 3 \text { criteria }) \\
\text { Mean } \pm \text { SD } \\
95 \% \text { CI }\end{array}$} & \multicolumn{2}{|c|}{ Anova } \\
\hline & Kuwait & Egypt & Kuwait & Egypt & Kuwait & Egypt & Kuwait & Egypt & Kuwait & Egypt \\
\hline Age & $\begin{array}{l}14.32 .3 \\
13.9-14.6\end{array}$ & $\begin{array}{l}13.91 .51 \\
13.8-13.9\end{array}$ & $\begin{array}{l}14.42 .2 \\
14.2-14.7\end{array}$ & $\begin{array}{l}14.21 .61 \\
14.1-14.3\end{array}$ & $\begin{array}{l}14.72 .1 \\
14.4-15.0\end{array}$ & $\begin{array}{l}14.31 .61 \\
14.2-14.4\end{array}$ & $\begin{array}{l}15.12 .2 \\
14.7-15.6\end{array}$ & $\begin{array}{l}14.51 .64 \\
14.3-14.6\end{array}$ & $<0.01$ & 0.001 \\
\hline $\begin{array}{l}\text { Waist } \\
\text { Circumference } \\
\text { (WC) }\end{array}$ & $\begin{array}{l}66.39 .4 \\
65.0-67.6\end{array}$ & $\begin{array}{l}62.97 .3 \\
62.6-63.2\end{array}$ & $\begin{array}{l}71.911 .2 \\
70.6-73.2\end{array}$ & $\begin{array}{l}67.08 .9 \\
66.5-67.5\end{array}$ & $\begin{array}{l}82.514 .1 \\
80.2-84.7\end{array}$ & $\begin{array}{l}71.511 .0 \\
70.6-72.3\end{array}$ & $\begin{array}{l}93.212 .8 \\
90.7-95.6\end{array}$ & $\begin{array}{l}76.812 .3 \\
75.4-78.2\end{array}$ & $<0.001$ & 0.001 \\
\hline BMI & $\begin{array}{l}22.24 .1 \\
21.7-22.8\end{array}$ & $\begin{array}{l}19.42 .5 \\
18.3-18.6\end{array}$ & $\begin{array}{l}24.75 .4 \\
24.0-25.3\end{array}$ & $\begin{array}{l}20.73 .86 \\
20.5-20.9\end{array}$ & $\begin{array}{l}28.96 .6 \\
27.8-29.9\end{array}$ & $\begin{array}{l}22.84 .6 \\
22.5-23.2\end{array}$ & $\begin{array}{l}32.75 .9 \\
31.5 \text { - } 33.8\end{array}$ & $\begin{array}{l}25.65 .5 \\
24.5-26.2\end{array}$ & $<0.001$ & 0.001 \\
\hline SBP & $\begin{array}{l}113.47 .4 \\
112.4-114 .\end{array}$ & $\begin{array}{c}101.311 .0 \\
4100.8-101.8\end{array}$ & $\begin{array}{l}121.310 .2 \\
120.1-122.5\end{array}$ & $\begin{array}{l}108.111 .7 \\
107.5-108 .\end{array}$ & $\begin{array}{c}127.89 .7 \\
7126.2-129 .\end{array}$ & $\begin{array}{c}114.711 .5 \\
3113.8-115.6\end{array}$ & $\begin{array}{l}131.910 .3 \\
129.9-133.9\end{array}$ & $\begin{array}{l}123.411 .9 \\
122.0-124.7\end{array}$ & $<0.001$ & 0.001 \\
\hline DBP & $\begin{array}{l}74.45 .4 \\
74.0-75.5\end{array}$ & $\begin{array}{l}63.67 .5 \\
63.3-63.9\end{array}$ & $\begin{array}{l}82.17 .8 \\
81.2-83.0\end{array}$ & $\begin{array}{l}69.99 .4 \\
69.5-70.5\end{array}$ & $\begin{array}{l}85.47 .8 \\
84.2-86.7\end{array}$ & $\begin{array}{l}75.48 .1 \\
74.8 \text { - } 76.1\end{array}$ & $\begin{array}{l}85.67 .5 \\
84.1 \text { - } 87.0\end{array}$ & $\begin{array}{l}79.56 .9 \\
78.7-80.2\end{array}$ & $<0.001$ & 0.001 \\
\hline FBG & $\begin{array}{l}88.46 .3 \\
87.6-89.3\end{array}$ & $\begin{array}{l}88.79 .8 \\
88.3 \text { - } 89.2\end{array}$ & $\begin{array}{l}92.16 .7 \\
91.3-92.9\end{array}$ & $\begin{array}{l}91.015 .4 \\
90.2-91.8\end{array}$ & $\begin{array}{l}92.47 .8 \\
91.1 \text { - } 93.6\end{array}$ & $\begin{array}{l}93.020 .3 \\
91.4-94.6\end{array}$ & $\begin{array}{l}98.221 .9 \\
93.9-102.5\end{array}$ & $\begin{array}{l}93.016 .1 \\
91.2-94.8\end{array}$ & $<0.001$ & 0.001 \\
\hline TG & $\begin{array}{l}52.119 .6 \\
49.3-54.7\end{array}$ & $\begin{array}{l}69.921 .0 \\
68.4-71.5\end{array}$ & $\begin{array}{l}59.824 .1 \\
56.9-62.7\end{array}$ & $\begin{array}{l}88.639 .9 \\
85.8-91.4\end{array}$ & $\begin{array}{l}76.238 .9 \\
69.9-82.3\end{array}$ & $\begin{array}{l}102.444 .3 \\
98.2-106.7\end{array}$ & $\begin{array}{l}129.369 .8 \\
115.8-142.8\end{array}$ & $\begin{array}{l}119.046 .8 \\
3113.2-124.8\end{array}$ & $<0.001$ & 0.001 \\
\hline HDL-C & $\begin{array}{l}52.49 .5 \\
51.1-53.7\end{array}$ & $\begin{array}{l}53.058 .3 \\
52.4-53.7\end{array}$ & $\begin{array}{l}46.711 .0 \\
45.3-48.0\end{array}$ & $\begin{array}{l}47.410 .5 \\
46.7-48.2\end{array}$ & $\begin{array}{l}39.59 .7 \\
37.9-41.1\end{array}$ & $\begin{array}{l}45.011 .2 \\
43.9-46.1\end{array}$ & $\begin{array}{l}34.79 .0 \\
32.9-36.4\end{array}$ & $\begin{array}{l}43.611 .4 \\
42.2-44.9\end{array}$ & $<0.001$ & 0.001 \\
\hline Insulin & $\begin{array}{l}12.97 .3 \\
11.9-14.0\end{array}$ & $\begin{array}{l}13.85 .5 \\
12.5-15.0\end{array}$ & $\begin{array}{l}15.89 .2 \\
14.6-16.9\end{array}$ & $\begin{array}{l}14.37 .5 \\
12.9-15.6\end{array}$ & $\begin{array}{l}25.324 .9 \\
21.2-29.4\end{array}$ & $\begin{array}{l}15.88 .2 \\
14.1-17.5\end{array}$ & $\begin{array}{l}34.832 .0 \\
28.4-41.1\end{array}$ & $\begin{array}{l}18.49 .7 \\
16.2-20.7\end{array}$ & $<0.001$ & 0.001 \\
\hline Homa-IR & $\begin{array}{l}2.81 .6 \\
2.6-3.1\end{array}$ & $\begin{array}{l}3.51 .5 \\
3.2-3.8\end{array}$ & $\begin{array}{l}3.62 .1 \\
3.3-3.8\end{array}$ & $\begin{array}{l}3.92 .5 \\
3.5-4.4\end{array}$ & $\begin{array}{l}5.96 .4 \\
4.8-6.9\end{array}$ & $\begin{array}{l}4.02 .0 \\
3.6-4.5\end{array}$ & $\begin{array}{l}8.68 .7 \\
6.9-10.3\end{array}$ & $\begin{array}{l}4.72 .7 \\
4.1-5.3\end{array}$ & $<0.001$ & 0.017 \\
\hline CRP & $\begin{array}{l}1.70 .5 \\
1.6-1.8\end{array}$ & $\begin{array}{l}2.50 .7 \\
2.3-2.8\end{array}$ & $\begin{array}{l}1.90 .6 \\
1.8-2.0\end{array}$ & $\begin{array}{l}2.5-0.7 \\
2.4-2.7\end{array}$ & $\begin{array}{l}2.20 .5 \\
2.1-2.3\end{array}$ & $\begin{array}{l}2.70 .7 \\
2.5-2.9\end{array}$ & $\begin{array}{l}2.40 .5 \\
2.3-2.5\end{array}$ & $\begin{array}{l}2.70 .7 \\
2.8-3.1\end{array}$ & $<0.001$ & 0.004 \\
\hline $\begin{array}{l}\text { Homo- } \\
\text { cysteine }\end{array}$ & $\begin{array}{l}0.70 .1 \\
0.7-0.8\end{array}$ & $\begin{array}{l}1.20 .2 \\
1.1-1.2\end{array}$ & $\begin{array}{l}0.80 .1 \\
0.7-0.8\end{array}$ & $\begin{array}{l}1.20 .2 \\
1.1-1.2\end{array}$ & $\begin{array}{l}0.80 .1 \\
0.8-0.9\end{array}$ & $\begin{array}{l}1.20 .2 \\
1.1-1.2\end{array}$ & $\begin{array}{l}0.80 .1 \\
0.8-0.9\end{array}$ & $\begin{array}{l}1.10 .2 \\
1.1-1.1\end{array}$ & $<0.001$ & 0.07 \\
\hline
\end{tabular}

MetS = metabolic syndrome; BMI = body mass index; FBG = fasting blood glucose; HDL = high density lipoprotein; TG = triglycerides; SBP = sys tolic blood pressure; DBP = diastolic blood pressure; CRP = C Reactive protein; $\mathrm{CI}$ = confidence interval.

Table 3. Comparing median and IQ range for CRP and homocysteine according to various parameters between adolescents from Kuwait and Egypt.

\begin{tabular}{|c|c|c|c|c|}
\hline & \multicolumn{2}{|c|}{ CRP $(\mu \mathrm{g} / \mathrm{dl})$} & \multicolumn{2}{|c|}{ Homocysteine ( $\mu \mathrm{mol} / \mathrm{L})$} \\
\hline & Median (IQ-Range) & Median (IQ-Range) & Median (IQ-Range) & Median (IQ-Range) \\
\hline & Kuwait & Egypt & Kuwait & Egypt \\
\hline \multicolumn{5}{|l|}{ Gender } \\
\hline Male & $130.0(40-445.5)$ & 381.8(160 - 2367.8) & $7.0(6.0-8.4)$ & $14.4(11.5-22.5)$ \\
\hline Female & $70.0(20-230.0)$ & $223.4(160-1835.0)$ & $5.6(4.6-7.2)$ & $12.1(9.5-16.5)$ \\
\hline \multicolumn{5}{|l|}{ Age group } \\
\hline$\leq 15$ & $100.0(30-384.0)$ & 236.5(160 - 1961.0) & $5.8(4.8-7.0)$ & $12.7(9.9-18.1)$ \\
\hline$>15$ & $90.0(30-228.7)$ & 415 (160 - 2861.1) & $7.1(5.6-8.6)$ & $13.9(10.8$ - 21.9) \\
\hline \multicolumn{5}{|l|}{ WC } \\
\hline$\leq 75$ percentile & $60.0(30-179.5)$ & $160(160$ - 1679.2) & $6.1(4.9-7.5)$ & 13.4(10.7 - 19.9) \\
\hline >75 percentile & $316.0(130-682.5)$ & $1214.3(160$ - 3609.7) & $7.0(5.4-8.3)$ & $13.2(9.9-17.8)$ \\
\hline \multicolumn{5}{|l|}{ Area of residence } \\
\hline Capital (K)/Capital (E) & $90.0(30-339.5)$ & 275.0(160 - 1988.1) & $5.6(4.6-6.7)$ & $12.2(9.7-16.2)$ \\
\hline Non-Capital (K)/Non-Capital (E) & $92.0(30-309.0)$ & $160.0(160-2107.0)$ & $7.0(5.4-8.3)$ & $18.5(13.3-24.3)$ \\
\hline
\end{tabular}

IQ range = interquartile range; $\mathrm{CRP}=\mathrm{C}$-reactive protein. 


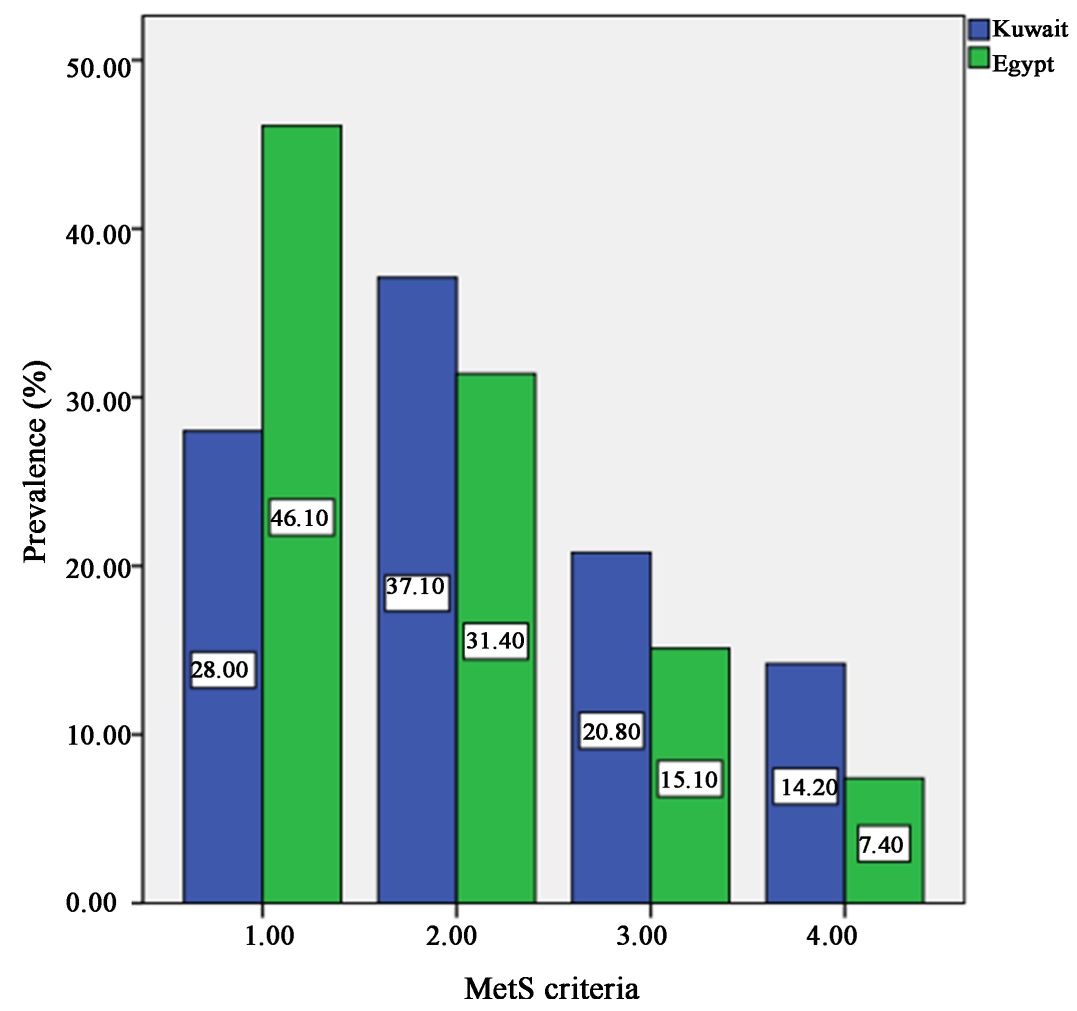

Figure 1. Comparing prevalence of MetS between adolescents of Kuwait and Egypt.

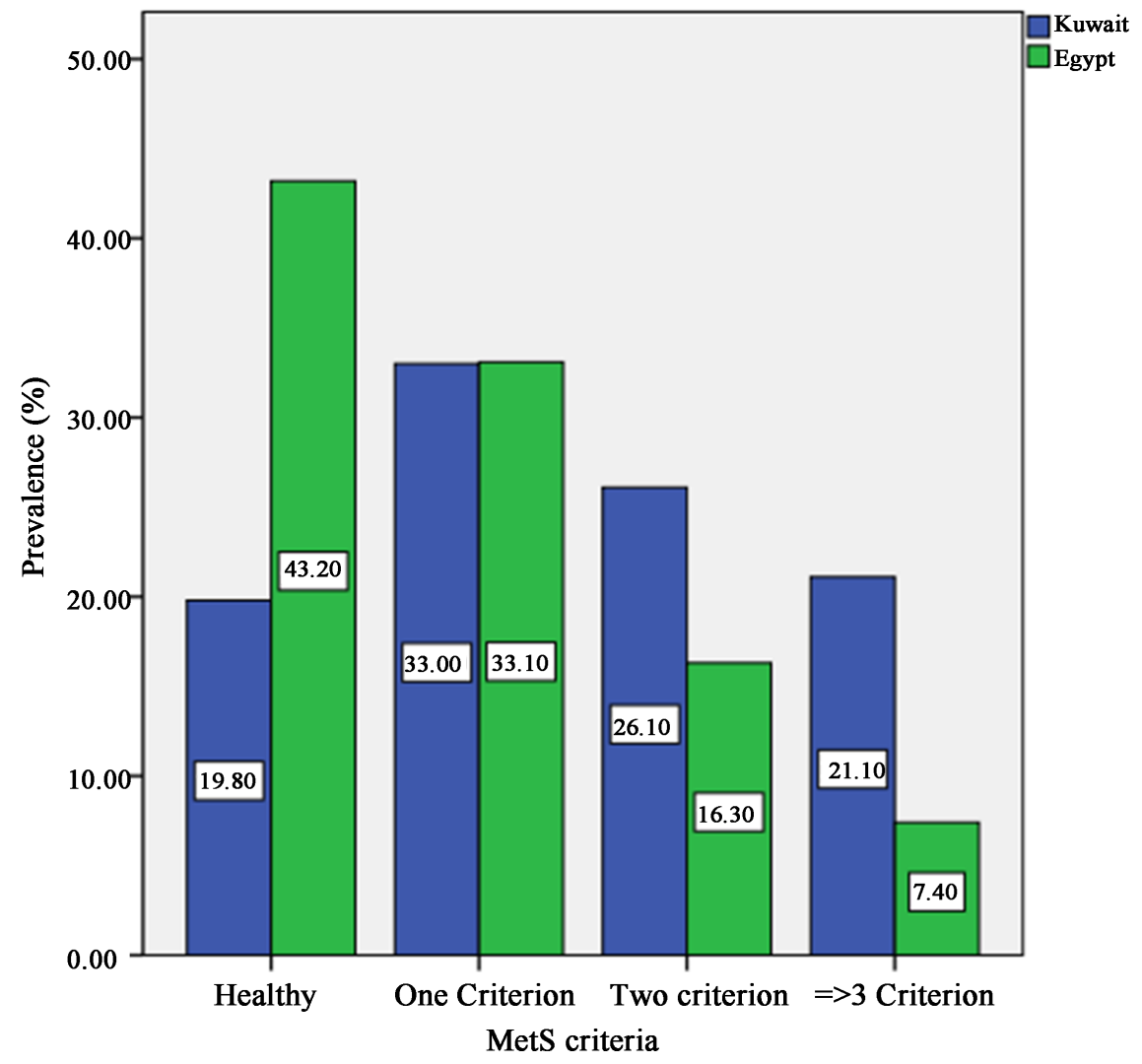

Figure 2. Comparing prevalence of MetS between male adolescents of Kuwait and Egypt. 
Table 4. Comparing metabolic syndrome (MetS) parameters per number of parameters between adolescents from Kuwait and Egypt.

\begin{tabular}{|c|c|c|c|c|c|c|c|c|}
\hline & \multicolumn{2}{|c|}{ MetS One parameter (\%) } & \multicolumn{2}{|c|}{ MetS Two parameters (\%) } & \multicolumn{2}{|c|}{ MetS $\geq 3$ Two parameters (\%) } & \multicolumn{2}{|c|}{ Total (\%) } \\
\hline & Kuwait & Egypt & Kuwait & Egypt & Kuwait & Egypt & Kuwait & Egypt \\
\hline BMI & 42.4 & 39.0 & 31.7 & 35.0 & 25.9 & 26.0 & 50.0 & 20.0 \\
\hline FBG & 47.9 & 45.0 & 30.1 & 31.0 & 22.0 & 24.0 & 9.8 & 4.0 \\
\hline HDL-C & 45.5 & 42.0 & 26.7 & 34.0 & 27.7 & 24.0 & 27.2 & 24.0 \\
\hline TG & 46.6 & 36.0 & 31.5 & 33.0 & 21.9 & 31.0 & 9.8 & 22.0 \\
\hline SBP & 50.4 & 20.0 & 30.8 & 38.0 & 18.8 & 42.0 & 54.3 & 11.0 \\
\hline DBP & 51.0 & 40.0 & 30.5 & 36.0 & 18.4 & 24.0 & 47.5 & 25.5 \\
\hline
\end{tabular}

MetS = metabolic syndrome; BMI = body mass index; FBG = fasting blood glucose; HDL = high density lipoprotein; TG = triglycerides; SBP = systolic blood pressure; DBP = diastolic blood pressure.

meters were present. Comparing among different MetS criteria showed significance (p-values $<0.001$ ) in all the groups except in MetS with one criterion.

Figure 3 compares the prevalence of MetS between female adolescents of Kuwait and Egypt. Under healthy conditions, the same was true as in Figure 2 and also for the presence of one or more parameters. Comparison among the first three MetS criteria showed significance (p-values $<0.001,<0.001$ and $<0.05$ ) except with the last criteria.

\section{Discussion}

The present study aimed at comparing the socio-demographic health-related, and biochemical factors associated with metabolic syndrome between adolescents of two Arab countries, which was a novel undertaking, to the best of the author's knowledge. According to the knowledge of this author, no study, before attempted to compare similar factors associated with MetS [13] [14].

There are no other studies that compared according to our knowledge MetS, among two Arab countries. Therefore we can only present the prevalence of MetS any related studies [15]-[27]. We can compare our results with studies of similar nature but there are none i.e. comparison between prevalence of MetS among two Arab countries.

In a study among adult Mediterranean population, it was found that gender, age, social class, BMI and smoking status were associated with and considered risk factors for MetS [28]. In a study among Jordanian children and adolescents, it was found that among 10 and under 16 years of age, girls had more MetS than boys. The reverse was true among those 16 or older. HDL cholesterol, blood pressure, and no, one, and three or more MetS abnormalities were associated with MetS. When multivariate analysis of factors associated with having at least one or more MetS parameters, it was found that children over 12 years of age influenced them having MetS for one or more and three or more components. Overweight was associated with MetS when one MetS abnormality present. However with obesity, all components were associated with MetS. North and Middle regions were associated with MetS when one component was present. Regular activities of more than seven hours per week were associated with MetS when three MetS parameters were present. [29]. MetS among Triglycerides, hypertension, low HDL cholesterol and WC were the factors associated with MetS among adolescent Mediterannean population [30]. Age BMI, education, income, sedentary life style, current smoking and low fresh fruit and vegetables were associated with MetS among Russian adults [31]. Age, gender, race, marital status, and education level were associated with MetS among out-patients with major depression, pre-existing hypertension, pre-existing diabetes mellitus and pre-existing hyperlipidemia were associated with MetS among Malaysian population. Life style risk factors for MetS among the same group included smoking, alcohol intake, and physical activity [32]. With the exception of age and gender, all metabolic characteristics were predictors of MetS [33]. Educational level was inversely associated with MetS [34]. The association between MetS, including BP, dyslipedmia, glucose intolerance and CRP decreased with increased physical activity [35]. Regarding the association of MetS with age of menarche in Bangladesh, it was found that as age decreases MetS increases. The same for central obesity, high fasting blood glucose decreased with age at menarche. High triglycerides increased with decreas- 


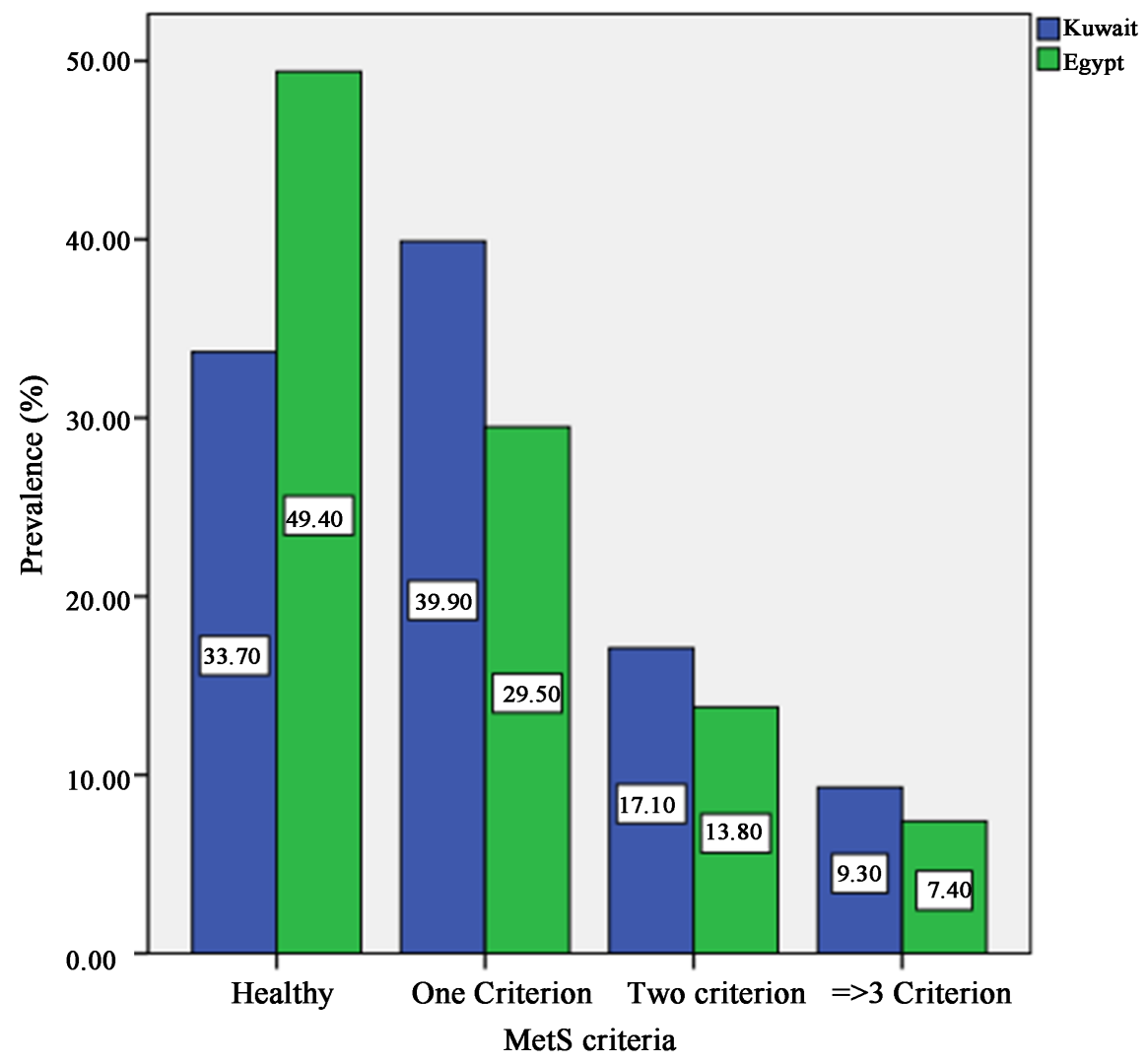

Figure 3. Comparing prevalence of MetS between female adolescents of Kuwait and Egypt.

ing age. The same was true for low HDL cholesterol. For high BP, the association with age was inconsistent [36]. In yet another study in the same country, the highest level of MetS was among women aged 45 - 54 years and one fifth of them had MetS, according to the IDF criteria. Owning a land, living area greater than $1000 \mathrm{sq} f t$, educational level, type of work, family history of diabetes and hypertension were associated with MetS [37]. We would have liked to compare the results of our study with similar studies done elsewhere but according to our knowledge there are no such studies.

To the best of the author's knowledge, no previous study attempted to compare socio-demographic healthrelated, and biochemical factors between two studies that addressed these issues. The few studies that addressed some of these issues among adults and even fewer among adolescents were searched to find socio-demographic, health-related, and biochemical factors associated with MetS. No study was found that addressed all those issues together. This study relied on studies that addressed some of these factors and cited them. It is hoped that future studies will attempt to follow the comparison made by this study.

\section{References}

[1] Mokdad, A.H., et al. (2004, 2005) Actual Causes of Death in the United States, 2000. Journal of the American Medical Association, 291, 1238-1245. Erratum in Journal of the American Medical Association, 293, 293-294, 298.

[2] Murry, C.J. and Lopez, A.D. (1997) Mortality by Cause for Eight Regions of the World. Global Burden of Disease Study. Lancet, 349, 1269-1276.

[3] Drygas, W., et al. (2000) Long-Term Effects on Different Physical Activity Levels On Coronary Heart Disease Risk Factors in Middle-Aged Men. International Journal of Sports Medicine, 21, 235-241.

[4] Hu, F.B., et al. (2001) Diet, Lifestyle, and the Risk of Type 2 Diabetes Mellitus in Women. The New England Journal of Medicine, 345, 790-797.

[5] Malekzadeh, R., et al. (2005) Obesity Pandemic: An Iranian Perspective. Archives of Iranian Medicine, 8, 1-7.

[6] Alberti, K.G.M.M., Zimmet, P.Z. and Shaw, J.E. (2005) The Metabolic Syndrome-A New World-Wide Definition 
from the International Diabetes Federation Consensus. Lancet, 366, 1059-1062. http://dx.doi.org/10.1016/S0140-6736(05)67402-8

[7] Khatib, O. (2004) Non-Communicable Diseases: Risk Factors and Regional Strategies for Prevention and Care. The Eastern Mediterranean Health Journal, 10, 778-788.

[8] Al-Isa, A.N. (2003) Are Kuwaitis Getting Fatter? Nutrition and Health, 17,185-197. http://dx.doi.org/10.1177/026010600301700301

[9] Al-Isa, A.N. (2004) Body Mass Index, Overweight and Obesity among Kuwaiti Intermediate School Adolescents Aged 10-14 Years. European Journal of Clinical Nutrition, 58, 1273-1277. http://dx.doi.org/10.1038/sj.ejcn.1601961

[10] Alberti, K.G., Zimmet, P. and Shaw, J. (2006) Metabolic Syndrome-A New World-Wide Definition. A Consensus Statement from the International Diabetes Federation. Diabetic Medicine, 23, 469-480. http://dx.doi.org/10.1111/j.1464-5491.2006.01858.x

[11] Cook, S., Weitzman, M. and Auinger, P., et al. (2003) Prevalence of a Metabolic Syndrome Phenotype in Adolescents. Archives of Pediatrics and Adolescent Medicine, 157, 821-827. http://dx.doi.org/10.1001/archpedi.157.8.821

[12] Grundy, S., Cleeman, J., Daniels, S., et al. (2005) Diagnosis and Management of the Metabolic Syndrome-An American Heart Association/National Heart, Lung, and Blood Institute Scientific Statement. Circulation, 112, 2735-2752. http://dx.doi.org/10.1161/CIRCULATIONAHA.105.169404

[13] Al-Isa, A.N. and Akanji, A.O. (2013) Socio-Demographic and Health-Related Determinants of Metabolic Syndrome (MetS) among Male Kuwaiti Adolescents Aged 10-19 Years. Health, 5, 720-727. http://dx.doi.org/10.4236/health.2013.54095

[14] Nebal, A.A.E., Dina, I.S., Mervat, A., et al. (2010) Prevalence of Metabolic Syndrome and Insulin Resistance among Egyptian adolescents 10 to 18 Years of Age. Journal of Clinical Lipidology, 4, 185-195. http://dx.doi.org/10.1016/j.jacl.2010.03.007

[15] Calcaterra, V., Klersy, C., Muratori, T., et al. (2007) Prevalence of Metabolic Syndrome (MS) in Children and Adolescents with Varying Degrees of Obesity. Clinical Endocrinology, 86, 868-872.

[16] Al-Isa, A.N., Abayomi, O.A. and Lukman, T. (2010) Prevalence of the Metabolic Syndrome among Female Kuwaiti Adolescents Using Two Different Criteria. British Journal of Nutrition, 103, 77-81. http://dx.doi.org/10.1017/S0007114509991425

[17] Ryu, S.Y., Kweon, S.S., Park, H.C., et al. (2007) Obesity and the Metabolic Syndrome in Korean Adolescents. Journal of Korean Medical Science, 22, 513-517. http://dx.doi.org/10.3346/jkms.2007.22.3.513

[18] Ford, E.S., Li, C., Zhao, G., et al. (2008) Prevalence of the Metabolic Syndrome among US Adolescents Using the Definition from the International Diabetes Federation. Diabetes Care Journal, 31, 587-589. http://dx.doi.org/10.2337/dc07-1030

[19] Xu, Y.Q. and Ji, C.Y. (2008) Prevalence of the Metabolic Syndrome in Secondary School Adolescents in Beijing, China. Acta Paediatrica, 97, 348-353. http://dx.doi.org/10.1111/j.1651-2227.2008.00665.x

[20] Lim, S., Jang, H.C., Park, K.S., et al. (2008) Changes in Metabolic Syndrome of Korean Children and Adolescents in the Period 1998 to 2001. Journal of Endocrinological Investigation, 31, 327-333.

[21] Esmaillzadeh, A., Mirmiran, P., Azadbakht, L., et al. (2006) High Prevalence of the Metabolic Syndrome in Iranian Adolescents. Obesity, 14, 377-382. http://dx.doi.org/10.1038/oby.2006.50

[22] Sartorio, A., Agosti, F., De Col, A., et al. (2007) Prevalence of the Metabolic Syndrome in Caucasian Obese Children and Adolescents, Comparison between Three Different Definition Criteria. Diabetes Research and Clinical Practice, 77, 341-342. http://dx.doi.org/10.1016/j.diabres.2006.12.010

[23] Jolliffe, C.J. and Janssen, I. (2007) Development of Age-Specific Adolescent Metabolic Syndrome Criteria That Are Linked to the Adult Treatment Panel III and International Diabetes Federation Criteria. Journal of the American College of Cardiology, 49, 891-898. http://dx.doi.org/10.1016/j.jacc.2006.08.065

[24] Agirbasli, M., Cakir, S., Ozme, S., et al. (2006) Metabolic Syndrome in Turkish Children and Adolescents. Metabolism, 55, 1002-1006. http://dx.doi.org/10.1016/j.metabol.2006.03.009

[25] Vissers, D., Vanroy, C., De Meulenaere, A., et al. (2007) Metabolic Syndrome in Youth: A Cross-Sectional School-Based Survey. Acta Paediatrica, 96, 1809-1813. http://dx.doi.org/10.1111/j.1651-2227.2007.00528.x

[26] Singh, R., Bhansali, A., Sialy, R., et al. (2007) Prevalence of Metabolic Syndrome in Adolescents from a North Indian Population. Diabetic Medicine, 24, 195-199. http://dx.doi.org/10.1111/j.1464-5491.2007.02066.x

[27] Wan, N.J., Mi, J., Wang, T.Y., et al. (2007) Metabolic Syndrome in Overweight and Obese School Children in Beijing. Zhonghua Er Ke Za Zhi, 45, 417-421.

[28] Buckland, G., Salas-Salvado, J., Roure, E., Bullo, M., Serra-Majem, L. (2008) Sociodemographic Risk Factors Asso- 
ciated with Metabolic Syndrome in a Mediterranean Population. Public Health Nutrition, 11, 1372-1378. http://dx.doi.org/10.1017/S1368980008003492

[29] Khader, Y., Baticha, A., Jaddon, H., El-Khateeb, M. and Ajlouni, K. (2010) Metabolic Syndrome and Its Individual Components among Jordanian Children and Adolescents. International Journal of Pediatric Endocrinology, 2010, 1-7. http://dx.doi.org/10.1155/2010/316170

[30] Tziallas, D., Kastanioli, C., Kostapanos, M.S., Skapinakis, P., Elisaf, M.S. and Mavreas, V. (2012) The Impact of the Metabolic Syndrome on Health-Related Quality of Life: A Cross-Sectional Study in Greece. European Journal of Cardiovascular Nursing, 11, 297-303.

[31] Bibiloni, M.M., Martinez, E., Llull, R., Maffiotte, E., Riesco, M., LLompart, I., Pons, A. and Tur, J.A. (2009) Metabolic Syndrome in Adolescents in the Balearic Islands, a Mediterranean Region. Nutrition, Metabolism and Cardiovascular Diseases, XX, 1-9.

[32] Sidorenkov, O., Nilssen, O. and Grijibovski, A.M. (2010) Metabolic Syndrome in Russian Adults: Associated Factors and Mortality from Cardiovascular Diseases and All Causes. BMC Public Health, 10, 1-10. http://dx.doi.org/10.1186/1471-2458-10-582

[33] Andrabi, S.M.S., Bhat, M., Andrabi, S.R.S., Kamili, M.M.A., Imran, A., Nisar, I. and Nisar, L. (2013) Prevalence of Metabolic Syndrome in 8 - 18 Year-Old School-Going Children of Srinagar City in Kashmir, India. Indian Journal of Endocrinology and Metabolism, 17, 95-100.

[34] Hat, N.H., Shahrul, A.M.H., Chong, L.L., Ee, W.S., Amirah, R., Hazli, Z. and Nik, R.N.J (2011) Factors Associated with Metabolic Syndrome among Psychiatric out Patients with Major Depressive Disorder. Medical Journal of Psychiatry, 1, 1-13.

[35] Hirschler, V., Oestreicher, K., Maccallini, G. and Aranda, C. (2010) Relationship between Obesity and Metabolic Syndrome among Argentinean Elementary School Children. Clinical Biochemistry, 41, 435-441. http://dx.doi.org/10.1016/j.clinbiochem.2009.11.003

[36] Ko, K.L.D., Cho, B., Lee, W.C., Lee, H.W., Lee, H.K. and Oh, B.J. (2010) Obesity Explains Gender Differences in the Association between Education Level and Metabolic Syndrome in South Korea. Asia Pacific Journal of Public Health, 1-6.

[37] Mirhosseini, N.Z., Shahar, S., Yusoff, N.A.M., Ghayour-Mobarhan, M.M., Dorakhshan, A.R. and Shakery, M.T. (2011) Lower Level of Physical Activity Predisposes Iranian Adolescent Girls to Obesity and Its Metabolic Consequences. Pakistani Journal of Nutrition, 10, 728-134. http://dx.doi.org/10.3923/pjn.2011.728.734

[38] Akter, S., Jesmin, S., Islam, M., Sultana, S.N., Okazaki, O., Miroe, M., Morgi M. and Mizutani, T. (2012) Association of Age at Menarche with Metabolic Syndrome and Its Components in Rural Bangladeshi Women. Nutrition and Metabolism, 9, 1-6.

[39] Jesmin, S., Islam, M.R., Islam, A.M.S., Mia, M.S., Sultana, S., Zaedi, S., Yamaguchi, N., Iwashima, Y., Hiroe, M. and Watanabe, T. (2012) Comprehensive Assessment of Metabolic Syndrome among Rural Bangladeshi Women. BMC Public Health, 12, 1-7. 


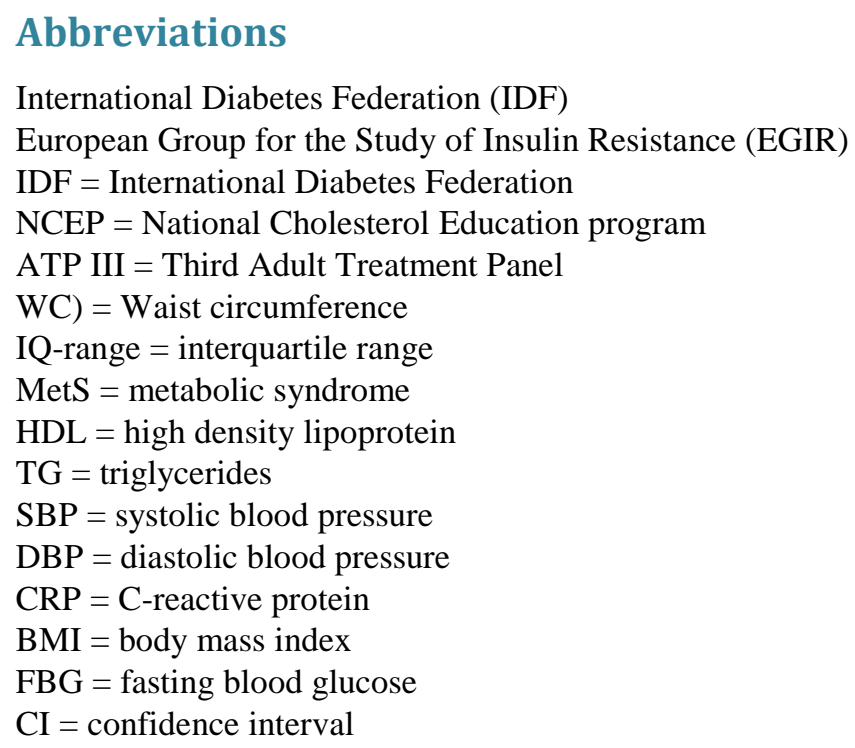

